\title{
Heterologous expression, purification and characterization of nitrilase from Aspergillus niger $\mathrm{K} 10$
}

Ondřej Kaplan ${ }^{1 \dagger}$, Karel Bezouška ${ }^{1,2+}$, Ondřej Plíhal ${ }^{1}$, Rüdiger Ettrich ${ }^{3}$, Natallia Kulik³, Ondřej Vaněk ${ }^{1,2}$, Daniel Kavan ${ }^{1,2}$, Oldřich Benada', Anna Malandra 1,4, Ondřej Šveda', Alicja B Veselá', Anna Rinágelová', Kristýna Slámová1, Maria Cantarella ${ }^{4}$, Jürgen Felsberg ${ }^{1}$, Jarmila Dušková, Jan Dohnálek', Michael Kotik, Vladimír Křen',

Ludmila Martínková ${ }^{*}$

\begin{abstract}
Background: Nitrilases attract increasing attention due to their utility in the mild hydrolysis of nitriles. According to activity and gene screening, filamentous fungi are a rich source of nitrilases distinct in evolution from their widely examined bacterial counterparts. However, fungal nitrilases have been less explored than the bacterial ones. Nitrilases are typically heterogeneous in their quaternary structures, forming short spirals and extended filaments, these features making their structural studies difficult.

Results: A nitrilase gene was amplified by PCR from the cDNA library of Aspergillus niger K10. The PCR product was ligated into expression vectors pET-30(+) and pRSET B to construct plasmids pOK101 and pOK102, respectively. The recombinant nitrilase (Nit-ANigRec) expressed in Escherichia coli BL21-Gold(DE3)(pOK101/pTf16) was purified with an about 2-fold increase in specific activity and 35\% yield. The apparent subunit size was $42.7 \mathrm{kDa}$, which is approx. $4 \mathrm{kDa}$ higher than that of the enzyme isolated from the native organism (Nit-ANigWT), indicating post-translational cleavage in the enzyme's native environment. Mass spectrometry analysis showed that a C-terminal peptide $\left(\left.V^{2}\right|_{327}\right.$ - Asn ${ }_{356}$ ) was present in Nit-ANigRec but missing in Nit-ANigWT and $\mathrm{Asp}_{298}-\mathrm{Val}_{313}$ peptide was shortened to Asp $_{298}-$ Arg $_{310}$ in Nit-ANigWT. The latter enzyme was thus truncated by 46 amino acids. Enzymes Nit-ANigRec and Nit-ANigWT differed in substrate specificity, acid/amide ratio, reaction optima and stability. Refolded recombinant enzyme stored for one month at $4^{\circ} \mathrm{C}$ was fractionated by gel filtration, and fractions were examined by electron microscopy. The late fractions were further analyzed by analytical centrifugation and dynamic light scattering, and shown to consist of a rather homogeneous protein species composed of 12-16 subunits. This hypothesis was consistent with electron microscopy and our modelling of the multimeric nitrilase, which supports an arrangement of dimers into helical segments as a plausible structural solution.

Conclusions: The nitrilase from Aspergillus niger K10 is highly homologous ( $\geq 86 \%)$ with proteins deduced from gene sequencing in Aspergillus and Penicillium genera. As the first of these proteins, it was shown to exhibit nitrilase activity towards organic nitriles. The comparison of the Nit-ANigRec and Nit-ANigWT suggested that the catalytic properties of nitrilases may be changed due to missing posttranslational cleavage of the former enzyme. Nit-ANigRec exhibits a lower tendency to form filaments and, moreover, the sample homogeneity can be further improved by in vitro protein refolding. The homogeneous protein species consisting of short spirals is expected to be more suitable for structural studies.
\end{abstract}

\footnotetext{
* Correspondence: martinko@biomed.cas.cz

† Contributed equally

'Institute of Microbiology, Academy of Sciences of the Czech Republic,

Vídeňská 1083, CZ-142 20 Prague, Czech Republic

Full list of author information is available at the end of the article
}

C Biomed Central

(c) 2011 Kaplan et al; licensee BioMed Central Ltd. This is an Open Access article distributed under the terms of the Creative Commons Attribution License (http://creativecommons.org/licenses/by/2.0), which permits unrestricted use, distribution, and reproduction in any medium, provided the original work is properly cited. 


\section{Background}

Nitrilases enable hydrolysis of nitriles to be performed under mild conditions and often in a stereo- or regioselective manner. These enzymes have thus great potential in organic synthesis but drawbacks such as instability, low activity or low selectivity lessen their practical use $[1,2]$. These limits may be overcome by searching for new nitrilases or improving known ones. Recently, the former approach has often made use of database mining [1-6].

According to GenBank search, not only bacteria, which have been intensively exploited as a source of nitrilases since the 1980s, but also filamentous fungi harbour a large number of nitrilase genes [7]. Apart from the teleomorph/anamorph pair Gibberella/Fusarium, the Aspergillus genus is a rich source of these enzymes, which exhibit low homology to bacterial nitrilases and thus may differ in their catalytic properties.

We have recently purified and characterized the first nitrilase in the Aspergillus genus, namely from the Aspergillus niger K10 strain [8], which was selected by nitrilase activity screening in filamentous fungi. In this study, the gene encoding this enzyme was amplified, cloned and sequenced and the protein deduced from gene sequencing was found to be highly homologous with a number of putative nitrilases in Aspergillus and Penicillium.

The natively expressed enzyme exhibited high specific activities towards (hetero) aromatic nitriles and was fairly stable under operational conditions for its use in nitrile hydrolysis [9]. Here, to potentiate its industrial utility, we expressed this enzyme in Escherichia coli. Heterologous expression has not been reported for any fungal nitrilases, as far as we know. On the other hand, a number of nitrilases from bacteria [1-4,6,10-13], and from the plant Arabidopsis thaliana [14,15] have been expressed in E. coli, as well as several cyanide hydratases from fungi [16].

Recombinant $E$. coli cells harbouring the $A$. niger gene produced the active enzyme (Nit-ANigRec). However, this enzyme differed in its catalytic properties from the wild-type enzyme that was purified from A. niger K10 (Nit-ANigWT). The quaternary structures of Nit-ANigRec and Nit-ANigWT were also different. Nitrilases and cyanide hydratases are proteins with unique structural properties, being able to exist in a number of different homooligomeric species - dimers, short homooligomeric spirals and extended helices [12,17-19]. The occurrence of these structural types in Nit-ANigRec and Nit-ANigWT was compared, indicating lower tendency of the former enzyme to form long helices. The homogeneity of this enzyme was enhanced by maturing (formation of species differing in molecular weight) during storage of the refolded enzyme, followed by size exclusion chromatography. The resulting protein appeared to be useful for analytical centrifugation and electron microscopy studies. It is also promising for nitrilase crystallization, which is thought to be impaired in enzymes forming the aforementioned helices [12].

A deeper insight into three-dimensional structures of nitrilases is impaired by missing crystal structures. The previous models of nitrilases from Pseudomonas fluorescens [1] and Rhodococcus rhodochrous [12,20] were therefore generated by exploiting their homology with crystallized members of the nitrilase superfamily. Here we have used an analogous approach to construct the first model of a fungal nitrilase, which is distantly related to the above bacterial enzymes.

\section{Results}

Determining the Aspergillus niger K10 nitrilase sequence Previously, the determination of the N-terminal amino acid sequence of Nit-ANigWT suggested a high similarity of this enzyme to a group of highly conserved putative nitrilases (with $\geq 90 \%$ amino acid identity) from the Aspergillus genus (Additional file 1). This enabled us to design degenerate primers, which were based on the $\mathrm{N}$-terminal and a conserved internal sequence of two putative Aspergillus fumigatus nitrilases. Combining the sequence data obtained from amplifications using both nitrilase-specific primers and from 5'-RACE and 3'RACE amplifications provided a complete sequence of the nitrilase gene (GenBank:ABX75546).

The amino acid sequence deduced from this nitrilase gene confirmed that Nit-ANigWT was highly similar to putative nitrilases from Aspergillus (A. clavatus, A. fumigatus, A. flavus, A. nidulans, A. oryzae, A. terreus) and Neosartorya fischeri (teleomorph of Aspergillus fischerianus). While our study of Nit-ANigWT sequencing was in progress, a sequence of a nitrilase-coding gene (GenBank: XP_001389844) from another A. niger strain (CBS 513.88) was deposited in the database. The amino acid sequence of this hypothetical protein was $99 \%$ identical to that of the enzyme being studied by us. Later, another very similar nitrilase (with $89 \%$ amino acid identity) (GenBank: XP_002562104) was sequenced in Penicillium chrysogenum. However, neither of these two nitrilases has been studied at the protein level.

\section{Nitrilase expression, purification and refolding}

The expression of the enzyme was achieved with the pOK101 and pOK102 vectors and 7 out of the $9 E$. coli strains tested (see Methods), the BL21(DE3) and BL21CodonPlus(DE3)-RIL strains being exceptions. The absence of nitrilase activity in these strains may have been caused by low transformation efficiency, endonuclease activity or limited translation due to codon bias. In all other strains, the nitrilase was expressed after 
IPTG addition and formed about one half of the soluble cellular proteins, as determined by SDS-PAGE (not shown). However, the nitrilase activities of the recombinant strains were not as high. Total activities of BL21 or Rosetta-gami strains were between 65 and $230 \mathrm{U} \mathrm{L}^{-1}$, while those of Arctic Express strains were on the average lower (34-150 $\left.\mathrm{U} \mathrm{L}^{-1}\right)$. These values were at most approx. twofold higher compared to those achieved in the native producer $A$. niger $\mathrm{K} 10$ (ca. $100 \mathrm{U} \mathrm{L}^{-1}$ ) [8]. However, the time required for maximum activity yield in $E$. coli was only $c a .20 \mathrm{~h}$, which was approx. three times less than in $A$. niger. Of the above E. coli strains, the highest activity of approx. $230 \mathrm{U} \mathrm{L}^{-1}$ was obtained in BL21-Gold(DE3) strain carrying the pOK101 plasmid (pET-30(+) containing the nit gene). Further increase in total activity to approx. $500 \mathrm{U} \mathrm{L}^{-1}$ was brought about by variation of cultivation parameters (IPTG concentration, induction time, temperature; data not shown) and by co-expression of pTf16 plasmid (coding for the trigger factor). However, the latter accounted for only about $10 \%$ increase in the total activity. This strain designated E. coli BL21-Gold(DE3)(pOK101/pTf16) has been used throughout further work. Nit-ANigRec was purified from this culture to near homogeneity with an approx. 2-fold increase in specific activity and $35 \%$ yield (Table 1 ). As expected from the nitrilase activity of the whole cells, the specific activity of the purified enzyme for benzonitrile $0.60 \mathrm{U} \mathrm{mg}^{-1}$ - was significantly (two orders of magnitude) lower than that of Nit-ANigWT - $91.6 \mathrm{U} \mathrm{mg}^{-1}$ [8].

As the above results suggested the possibility of incorrect protein folding, the protein was fully denatured in $6 \mathrm{M}$ guanidine- $\mathrm{HCl}$ and $2 \mathrm{M}$ TCEP (tris-carboxyethylphosphine), and refolded in vitro. However, the best refolding conditions (see Methods) selected by screening the commercial iFOLD 1 system merely led to the recovery of the initial activity and not to its improvement.

According to SDS-PAGE analysis (not shown), the apparent molecular weight of the subunit of the purified enzyme $(42.7 \mathrm{kDa})$ was higher than that of Nit-ANigWT - 38.5 kDa [8]. This indicated that the latter protein underwent a post-translational modification in its native environment. In order to clarify the molecular nature of this difference, we performed N-terminal sequencing and peptide mass mapping with both Nit-ANigRec and Nit-ANigWT (Figure 1). The N-terminal sequence of both enzymes was identical, indicating that the processing occurred most probably at the C-terminus of the enzyme. Indeed, peptide mass mapping using both trypsin and Asp-N in gel digestion revealed that the C-terminal tryptic peptide $\mathrm{Val}_{327}-\mathrm{Asn}_{356}$ was present in Nit-ANigRec but absent in Nit-ANigWT. More specifically, the Asp-N generated peptide $\mathrm{Asp}_{298}-\mathrm{Val}_{313}$ detected in the recombinant protein was shortened to $\mathrm{Asp}_{298}-\mathrm{Arg}_{310}$ in the native enzyme. These results provide evidence that Nit-ANigWT was shortened by 46 amino acid residues at the $\mathrm{C}$-terminus, and is composed of Met $_{1}-\mathrm{Arg}_{310}$ of amino acid sequence coded by the corresponding nitrilase gene.

\section{Preparation of homogeneous enzyme for structural studies}

Electron microscopy study of Nit-ANigRec showed heterogeneous population of particles of different shapes from nearly isometric ones in size of about $14 \mathrm{~nm}$ to elongated ones reaching over $30 \mathrm{~nm}$ in length. Additionally, smaller particles of different shapes and some bigger clusters were also observed (Additional file 2). However, long filamentous structures typical for NitANigWT [17] were not observed in this sample. Despite the limited ability of Nit-ANigRec to form the aforementioned filamentous structures, the purified enzyme was not suitable for structural studies or protein crystallography. The refolded protein (see above) also still exhibited some molecular heterogeneity as revealed by electron microscopy (Additional file 3). Though the gelfiltration chromatography fractionated the refolded enzyme as a single major peak ( $\mathrm{Mw} \cong 600 \mathrm{kDa})$, peak fronting and the appearance of a minor peak preceding the major one suggested that a small part of the enzyme aggregated into higher-molecular weight species (Figure 2A). After a 1-month storage of the major-peak protein fraction at $4^{\circ} \mathrm{C}$, this aggregation occurred again, as well as a notable shift of the molecular mass of the enzyme towards lower values (about $500 \mathrm{kDa}$; Figure 2B). After removing the aggregated form, the rest of the enzyme remained rather stable, since after 10 more days of storage under the same conditions, fewer aggregates could be observed, without any further change in enzyme size (Figure 2C). Nevertheless, even after such "maturation" in enzyme quaternary structure, the enzyme was

Table 1 Purification of recombinant nitrilase from Aspergillus niger K10

\begin{tabular}{clllll}
\hline Step & $\begin{array}{l}\text { Total protein, } \\
\text { mg }\end{array}$ & $\begin{array}{l}\text { Specific activity, } \\
\mathbf{U ~ m g ~}^{-1}\end{array}$ & $\begin{array}{l}\text { Total activity, } \\
\text { U }\end{array}$ & $\begin{array}{l}\text { Yield, } \\
\%\end{array}$ & $\begin{array}{l}\text { Purification, } \\
\text { fold }\end{array}$ \\
\hline Cell-free extract & 444.4 & 0.29 & 130.5 & 100 & - \\
Q-Sepharose & 159.5 & 0.39 & 61.5 & 43.2 & 1.34 \\
Sephacryl S-200 & 76.7 & 0.60 & 46.1 & 35.1 & 2.07 \\
\hline
\end{tabular}

Enzyme activity was assayed with $25 \mathrm{mM}$ benzonitrile (see Methods for details). 


\section{Nit-ANigWT}
1 MAPVLKKYKA AAVNAEPGWF NLEESVRRTI
51 I $\overline{\text { PGYPYWMWK }} \overline{\mathrm{V} N Y Q E \bar{S} L P L L}$ KKYRENSLPS
HWIDEAGKAG CKFIAFPELW
101 LGYSEVDLAS LYTTQVMISP SGDILNHRRK DSDEMRRIRN AARANKIYVS
151 SVIQTDIGRV GHLNCWENMN PEMKAYAASL IRATHVERLV FGDGTGDTTE
201 PDPFTNVAEA NADLVTPAYA
IETGTYTLAP
GEQVHVAAWP
LYPGKETLKY
251 DPHIYNGHGR IFGPDGQNLV PHPDKDFEGI
WQTITAEGIK
LNTPPGKDLE
301 GHYMRPDLIR*

\section{Nit-ANigRec}

\section{MAPVLKKYKA AAVNAEPGWF NLEESVRRTI HWIDEAGKAG CKFIAFPELW

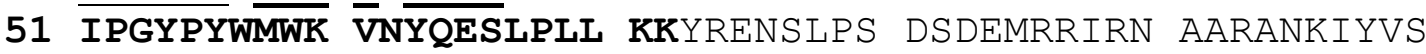 \\ 101 LGYSEVDLAS LYTTQVMISP SGDILNHRRK IRATHVERIV FGDGTGDTTE \\ 151 SVIQTDIGRV GHLNCWENMN PEMKAYAASL GEQVHVAAWP LYPGKETLKY \\ 201 PDPFTNVAEA NADLVTPAYA IETGTYTLAP WQTITAEGIK INTPPGKDLE \\ 251 DPHIYNGHGR IFGPDGQNLV PHPDKDFEGL LFVDIDLDEC HLSKSLADFG \\ 301 GHYMRPDLIR*LLVDTNRKDL VVREDRVNGG VEYTRTVDRV GLSTPLDIAN \\ 351 TVDSEN}

Figure 1 Summary of the sequence analysis of heterologously expressed nitrilase vs. nitrilase isolated from the native organism (NitANigRec and Nit-ANigWT respectively). Sequence analysis was performed by automated Edman degradation of nitrilase blotted onto PVDF membrane (underlined) in combination with peptide mass mapping using MALDI TOF mass spectrometry of peptides extracted after in gel digestion with trypsin (bold) or Asp-N protease (italics). The position of C-terminal truncation by 46 amino acids in the native preparation is indicated by an asterisk.

composed of a rather heterogeneous mixture of molecular forms, which were separated by gel filtration and examined by electron microscopy (Figure 2D through $2 \mathrm{G})$. In the early eluting fractions the enzyme occurred in the form of short tubes and was rather heterogeneous, whereas the late eluting fractions contained the enzyme in more homogeneous forms (cf. Figure 2Dvs. 2G).

Data obtained from sedimentation velocity analysis of the latter fractions (Figure 2H) suggested a rather broad mass distribution of sedimenting species with values of apparent sedimentation coefficients ranging between 10 and 30S, the majority (approx. 70\%) of particles falling between 12 and 22S, in 95\% confidence level. Integration of size distribution for the main particle fraction yielded a weight average sedimentation coefficient $\mathrm{s}^{*}=$ $16.8 \pm 2.4 \mathrm{~S}\left(\mathrm{~s}_{20, \mathrm{w}}=17.8 \pm 2.0 \mathrm{~S}\right)$ and a frictional coefficient ratio $\mathrm{f} / \mathrm{f}_{0}=1.42$ corresponding to a moderately elongated particle. Global analysis of sedimentation equilibrium data (Figure 2I) resulted in weight average particle mass of $564 \pm 5 \mathrm{kDa}$ in $95 \%$ confidence level, with almost no observable tendency to aggregate in the time course of the experiment (as judged from the residual plot of fit analysis). Based on the value of sedimentation coefficient, frictional coefficient ratio and observed particle mass, the size and shape of the majority of particles was estimated as $20 \times 10 \pm 5 \mathrm{~nm}$ and this correlates with electron microscopy (Figure 2G). Taking into account the theoretical molar mass of nitrilase monomer is $40 \mathrm{kDa}$, we can conclude that majority of observed nitrilase oligomers was composed of $14 \pm$ 2 nitrilase subunits, as deduced from a combination of data from SDS electrophoresis, gel filtration, electron microscopy and analytical ultracentrifugation, although higher oligomers were still present in significant amount.

In agreement with the results obtained by other techniques, DLS (dynamic light scattering) measurements (Table 2) confirmed the gradual decrease in size in the above protein fractions starting with $22.8 \mathrm{~nm}$ oligomers $(\mathrm{Mw}>1 \mathrm{MDa})$ down to particles having a diameter of about $14.8 \mathrm{~nm}(\mathrm{Mw} \cong 370 \pm 50 \mathrm{kDa})$. All fractions analysed by DLS (Table 2) are polydisperse with a polydispersity index (PdI) in the range 0.23-0.30 with equal data quality. Fractions with the lowest PdI correspond to the second half of the gel filtration peak. The smallest particle size and the highest homogeneity make these fractions most suitable for further analyses including prospective protein crystallization attempts. 

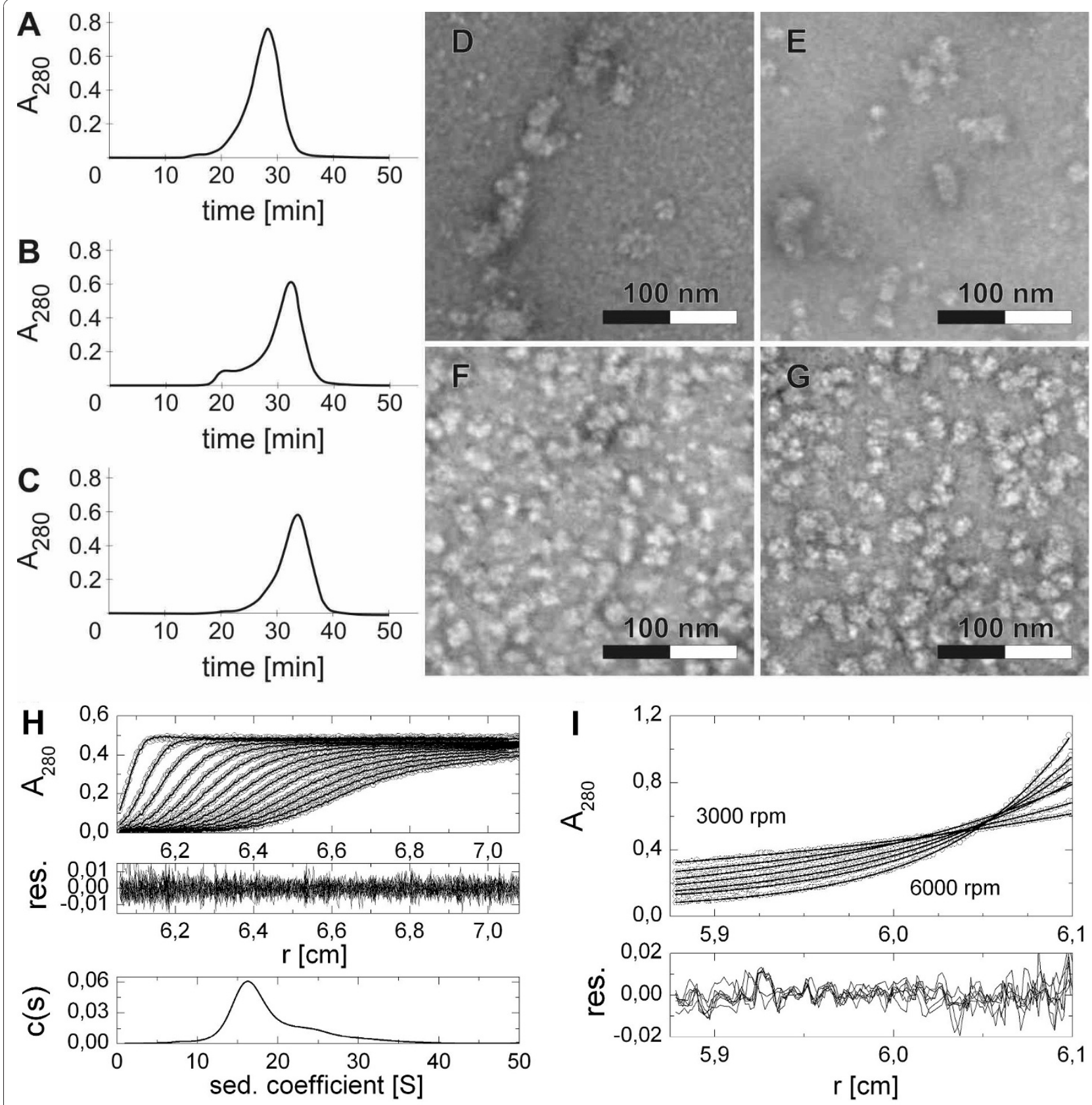

Figure 2 Effect of aging on the quaternary structure of recombinant refolded nitrilase. Gel filtration analysis on Superose 6B of freshly refolded enzyme (A), and enzyme stored for 30 and 40 days at $4^{\circ} \mathrm{C}$ (B and $\mathrm{C}$, respectively). Fractions were collected from the last separation, and analyzed by electron microscopy using material eluted between 26 and $27 \mathrm{~min}(\mathrm{D}), 30$ and $31 \mathrm{~min}(\mathrm{E}), 33$ and $34 \mathrm{~min}(\mathrm{~F})$, and 37-38 min (G). The homogeneous round-shaped particles observed in the latter fractions $(\mathrm{G})$ were analyzed in an analytical ultracentrifuge using sedimentation velocity $(\mathrm{H})$ and sedimentation equilibrium (I) experiments as detailed in Methods. Fitted data with residual plots showing goodness of fit are shown together with calculated continuous size distribution $c(s)$ of sedimenting species.

\section{Homology modelling and molecular dynamics}

A BLAST search identified five proteins with relevant known structures: the NitFhit protein from Caenorhabditis elegans (pdb-code 1EMS) [21]; hypothetical protein Ph0642 from Pyrococcus horikoshii (1J31) [22]; Nit3 protein from Saccharomyces cerevisiae (a member of branch
10 of the nitrilase superfamily, pdb-code 1F89) [23]; the pyrimidine degrading enzyme from Drosophila melanogaster (2VHH) [24] and mouse nitrilase-2 (2W1V) [25] with corresponding identities of $22,23,20,21$ and $22 \%$. Although the percentage of identity is at the lower threshold for homology modelling, 3D alignment with 
Table 2 Measurement of size and heterogeneity of recombinant refolded nitrilase in fractions separated by gel filtration (see Figure 2) using dynamic light scattering (DLS)

\begin{tabular}{cccc}
\hline Elution time, $\mathbf{m i n}$ & Diameter, $\mathbf{n m}$ & Mw, kDa & Pdl \\
\hline 32 & 22.8 & 1000 & 0.30 \\
34 & 19.7 & 710 & 0.24 \\
36 & 17.0 & 500 & 0.29 \\
38 & 14.5 & 350 & 0.23 \\
40 & 14.8 & 370 & 0.23 \\
\hline
\end{tabular}

$\mathrm{Pdl}=$ polydispersity index

the SHEBA plug-in in YASARA showed a high conservation of secondary structure elements among the selected templates, thus supporting the attempt to at least obtain a useful low-resolution homology model. The C-terminal part (residues 316-356) was modelled based on the crystal structure of kinesin from Rattus norvegicus (2KIN, 29\% of identity) [26] using residues 136-183 as a template, as this part has been lost in hydrolases. Figure 3 shows a structure-based multiple sequence alignment of nitrilase from Aspergillus niger with selected templates and sequences of previously published homology models of nitrilases from $R$. rhodochrous J1 [12,20] (identity 38\%) and Pseudomonas fluorescens [1] (26\%). Secondary structure is given as assigned by Procheck [27]. Figure 4A shows a view of the enzyme with the catalytic domain on the left and the active site in the domain center. The three long loops at the entrance of the active site are interesting features of the modelled structure. Loops including the residues that correspond to 236-252 and 55-64 between $\beta 2$ and $\alpha 2$ and $236-252$ between $\beta 10-\beta 12$ (coloured magenta in Figure 4A) in the primary sequence were found in just one template structure, $2 \mathrm{VHH}$, but these residues were not resolved in the crystal structure [24]. A loop corresponding to 196-207 between $\beta 8$ and $\alpha 6$ (yellow in Figure 4A) was not found in any template structure (Additional file 4). The nitrilase from Rhodococcus rhodochrous $\mathrm{J1}$ [12] presents similar residues at the corresponding primary sequence positions, and similar external loops in its homology model. The nitrilase from Pseudomonas fluorescens lacks the insertion at the position similar to 196-207 but it has one additional loop between $\beta 14$ and $\alpha 7$.

A docking attempt in AutoDock, using benzonitrile as the substrate, found a position in the centre of the enzyme with the lowest binding energy, and thus the highest affinity. This position involved the predicted triad of active residues (Figure 4B; Additional file 4), demonstrating the basic correctness of the modelled structure.

The geometrical parameters of spiral structures obtained from electron microscopy were used to draft a plausible multimeric arrangement. The electron micrographs corresponded in size and general shape to helical segments made up of dimers (Figure 5A and 5C). Hereby, taking into account the size and shape of the monomeric model, approximately 16 subunits would be organized in a spiral or helical arrangement and 8 dimers would form one helical turn that could be extended in both directions (Figure 5B and 5D). Similar loops are found at the $\mathrm{C}$-surface in the helical-like form of the nitrilase from $R$. rhodochrous [12]. 14-16 subunits in the multimeric structure can be assumed for the aliphatic nitrilase from $R$. rhodochrous K22 [28] which has an identity of $42 \%$ with the nitrilase from A. niger K10.

\section{Comparison of reaction optima, substrate specificity,} selectivity and stability of the heterologously expressed nitrilase and the nitrilase isolated from the native organism

The optimal reaction conditions of Nit-ANigRec and Nit-ANigWT were different. Nit-ANigRec exhibited a lower temperature optimum $\left(38 v s .45^{\circ} \mathrm{C}\right)$ when assayed after 10 -min reaction time. Its activity decreased to 55 and $4 \%$ at 45 and $50^{\circ} \mathrm{C}$, respectively, while Nit-ANigWT retained significant activity up to $55^{\circ} \mathrm{C}$. The $\mathrm{pH}$-range of Nit-ANigRec (ca. pH 5.5-9.5) was slightly shifted towards lower values compared to that of Nit-ANigWT (ca. pH 6-10).

Nit-ANigRec, incubated for $1 \mathrm{~h}$ at 40,45 and $50^{\circ} \mathrm{C}$, exhibited a residual activity $>80,36$ and $1.3 \%$, respectively. Its stability was thus lower than that of NitANigWT, which still exhibited 59, 24 and $6 \%$ of the maximum activity after 1 -h incubation at 45,50 and $55^{\circ}$ $\mathrm{C}$, respectively. The effects of various additives on NitANigRec activity were similar to those reported for the Nit-ANigWT [8]. $p$-Hydroxymercuribenzoate, $\mathrm{Hg}^{2+}, \mathrm{Ag}^{+}$ and $\mathrm{Al}^{3+}$ ions completely abolished the activity of both preparations.

The relative activities of Nit-ANigWT decreased in the order 4-cyanopyridine $>$ benzonitrile $>3$-chlorobenzonitrile $>4$-chlorobenzonitrile $>$ phenylacetonitrile $>3$ cyanopyridine $>2$-cyanopyridine $>>2$-phenylpropionitrile. In contrast, the best substrate of Nit-ANigRec was 2-cyanopyridine, followed by 3-cyanopyridine and 3chlorobenzonitrile (Table 3). Thus 2-cyanopyridine was the only substrate for which Nit-ANigRec exhibited a similar or higher activity $\left(9 \mathrm{U} \mathrm{mg}^{-1}\right.$ of protein at $38^{\circ} \mathrm{C}$ after 10 -min reaction time or $26 \mathrm{U} \mathrm{mg}^{-1}$ of protein $45^{\circ} \mathrm{C}$ after 1 -min reaction time) compared to Nit-ANigWT (7 $\mathrm{U} \mathrm{mg}^{-1}$ of protein at $45^{\circ} \mathrm{C}$ after 10 -min reaction time). Other substrates were transformed at very low rates or not transformed at all. In Nit-ANigRec, the production of amide by-product was most significant with 2-cyanopyridine (23\% amide in total product). Nevertheless, this was much less than with Nit-ANigWT, which 


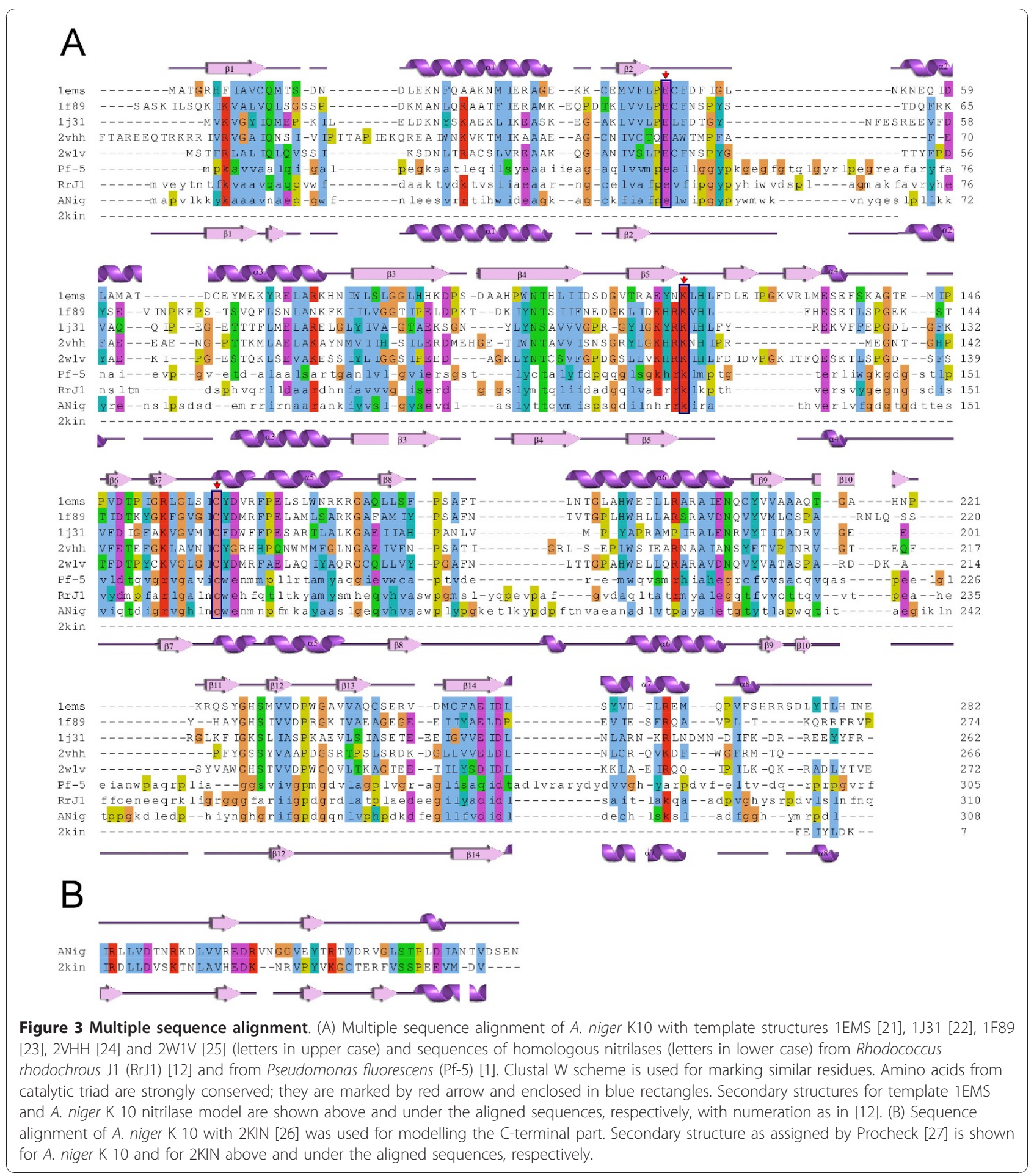

gave a product consisting of up to $88 \%$ picolinamide. From the other substrates tested, the recombinant nitrilase produced only a maximum of $5 \%$ amide in the total product, in contrast to the enzyme isolated from the native organism producing high amounts of amides also from 4-chlorobenzonitrile and 4-cyanopyridine (Table 3).
All the compounds tested as potential stabilizers of the nitrilase (sugars, sugar alcohols, albumin, glycine) improved the Nit-ANigRec stability to a significant extent during either incubation at $38^{\circ} \mathrm{C}$ or repeated freezing/thawing cycles (Table 4). Without any stabilizer, the enzyme retained about 36 and $60 \%$ of its initial 
A

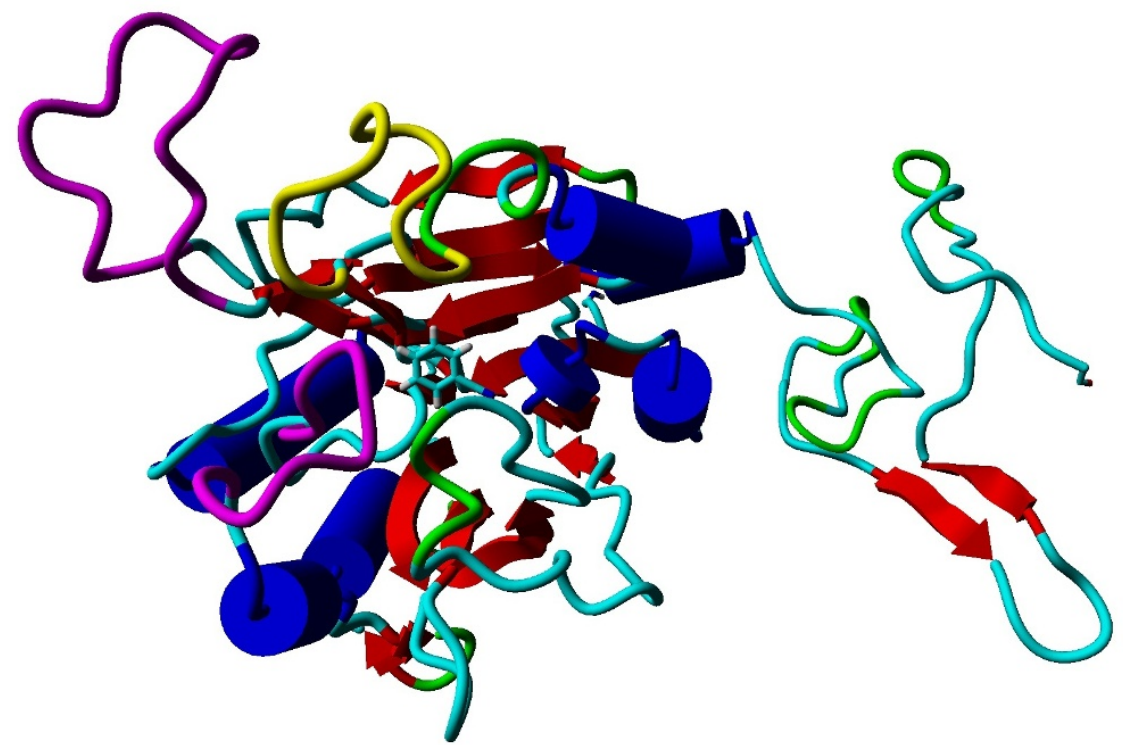

B

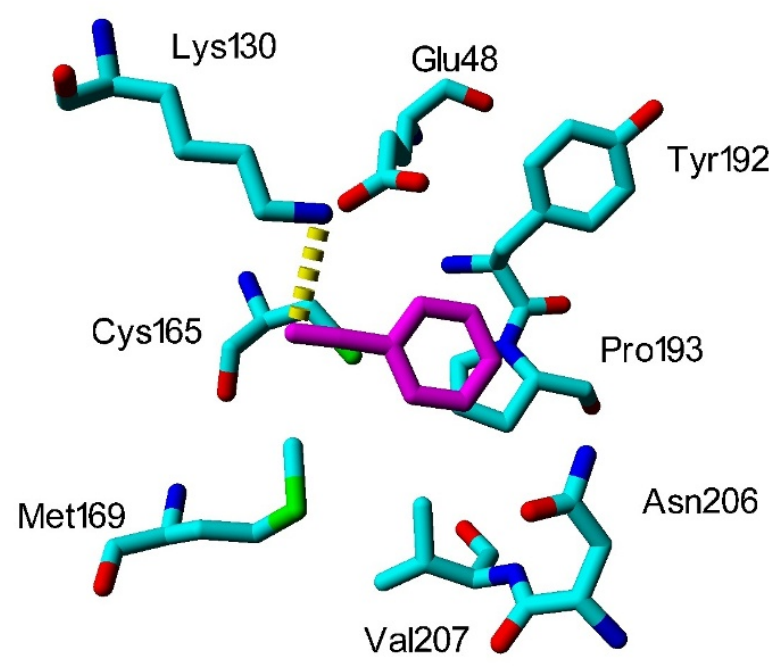

Figure 4 Homology model of nitrilase (A) and active site amino acids (B) with docked benzonitrile. Loops formed by residues 55-64 and 236-252 are coloured magenta and loop formed by residues 196-207 is yellow. The catalytic domain is on the left side. Active site amino acids with docked benzonitrile (magenta) after $2 \mathrm{~ns}$ of molecular dynamics simulation (B). Hydrogen atoms are omitted. The catalytic triad is represented by Glu 48, Lys 130 and Cys 165. The only hydrogen bond (yellow dotted line) is created by hydrogen atom of Lys 130 and nitrogen of benzonitrile. 


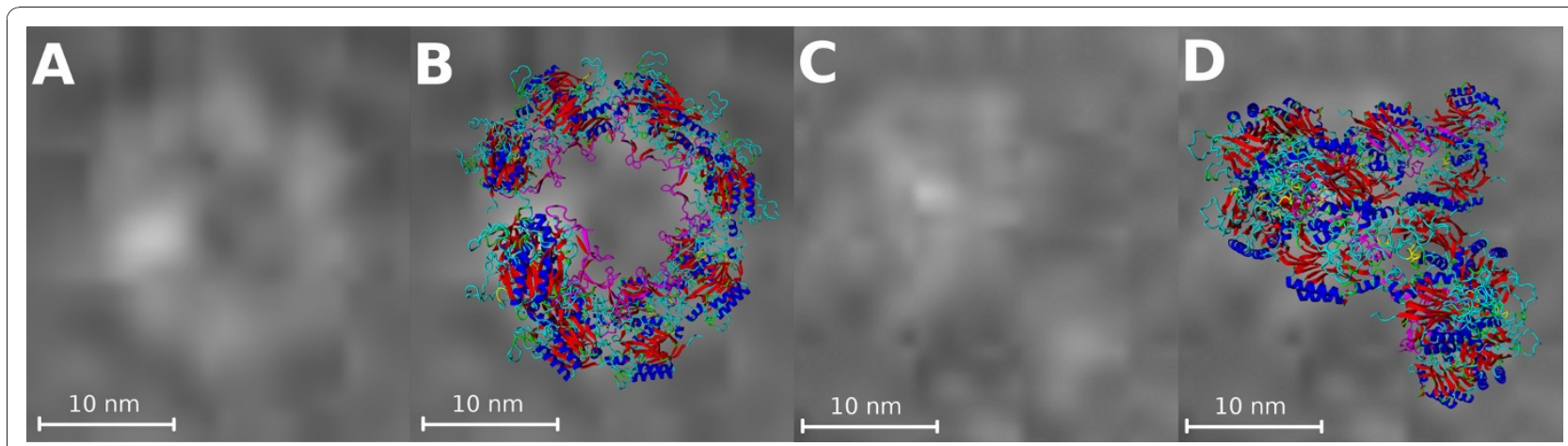

Figure 5 Nitrilase multimer. (A) and (C) panels are images from electron microscope, (B) and (D) - overlay of top view and side view, respectively, of constructed multimer and image from electron microscope.

activity, respectively, but full activity was preserved in the presence of $1 \%$ glycine as the most powerful stabilizer. The combined action of freezing/thawing (20 cycles) and 3-h incubation at $45^{\circ} \mathrm{C}$ decreased nitrilase activity by $>90 \%$ (to $0.057 \mathrm{U} \mathrm{mg}^{-1}$ protein). However, the same treatment in the presence of glycine, D-sorbitol, xylitol or glucose (5\% each) allowed a 4-5-fold higher enzyme activity recovery (data not shown). A mixture of glycine and ammonium sulfate proved to be most efficient, enhancing the final activity by nearly a factor of 14 compared to the control without stabilizer.

\section{Discussion}

A large number of putative nitrilase and cyanide hydratase sequences are contained within the whole genomic sequences of fungi. As far as we know, none of the sequenced fungal nitrilases which were predicted to act on organic nitriles have been characterized, contrary to the situation with the fungal cyanide hydratases. Likewise, no sequence data have been available for the characterized nitrilases from Fusarium solani IMI196840 [29] and Fusarium oxysporum f. sp. melonis [30]. Only recently have partial amino acid sequences been identified in the nitrilases from Fusarium solani O1 [17] and Fusarium solani IMI196840 [31], the latter enzyme being probably different from that previously characterized in the same strain [29].

The putative nitrilases of the Aspergillus genus can be roughly divided into two groups, which share a relatively low degree of amino acid identity (30-40\%) [7]. One of these groups is closely related to cyanide hydratases (with ca. 60-85\% amino acid identity) and the A. niger K10 nitrilase was shown to be a member of this group. The high tendency of this enzyme to form amides from nitriles [8] is in accordance with its evolutionary relationship to cyanide hydratases, the reaction product of which is formamide [16,32].

The heterologous expression of the enzyme in E. coli BL21-Gold(DE3)(pOK101/pTf16) led to a notable increase in enzyme productivity $\left(25.8 \mathrm{U} \mathrm{L}^{-1} \mathrm{~h}^{-1}\right)$ under optimized conditions, which was fifteen times higher than in the native producer (approx. $1.7 \mathrm{U} \mathrm{L}^{-1} \mathrm{~h}^{-1}$ ). The potential to synthesize the active enzyme may be even higher in the heterologous producer as indicated by the

Table 3 Substrate specificity and chemoselectivity of purified nitrilase isolated from A. niger K10 (Nit-ANigWT) and heterologously expressed nitrilase (Nit-ANigRec)

\begin{tabular}{lcccc}
\hline Substrate & \multicolumn{2}{c}{ Relative activity, \% } & \multicolumn{2}{c}{ Amide, molar \% of total product } \\
\cline { 2 - 5 } & Nit-ANigWT & Nit-ANigRec & Nit-ANigWT & Nit-ANigRec \\
\hline Benzonitrile & 27 & 4.9 & 0 & 0 \\
2-Chlorobenzonitrile & 0 & 0 & 3 & - \\
3-Chlorobenzonitrile & 10 & 3.7 & 80 & 5 \\
4-Chlorobenzonitrile & 8.4 & 0.2 & 88 & 0 \\
2-Cyanopyridine & 2.4 & 100 & 6 & 23 \\
3-Cyanopyridine & 4.6 & 12.9 & 36 & 0 \\
4-Cyanopyridine & 100 & 0.8 & 0 & 0 \\
Phenylacetonitrile & 4.9 & 0.2 & 0 & 0 \\
2-Phenylpropionitrile & traces & 0 & & 0 \\
\hline
\end{tabular}

Enzyme activity was assayed as described in Methods. The specific activities of Nit-ANigWT and Nit-ANigRec for their best substrates 4 -cyanopyridine (306 $U$ mg ${ }^{-1}$ at $\left.45^{\circ} \mathrm{C}\right)$ and 2 -cyanopyridine $\left(9.0 \mathrm{U} \mathrm{mg}^{-1}\right.$ at $\left.38^{\circ} \mathrm{C}\right)$, respectively, were taken as $100 \%$. Data represent the mean of four independent measurements with relative standard deviation values $<5 \%$. 
Table 4 Effect of potential stabilizers on nitrilase activity

\begin{tabular}{lcc}
\hline Compound (concentration) & \multicolumn{2}{c}{ Residual activity, \% } \\
& Method A & Method B \\
\hline None & 36.3 & 60 \\
Glycine $(1 \%, \mathrm{w} / \mathrm{v})$ & 100 & 100 \\
Sucrose $(10 \%, \mathrm{w} / \mathrm{v})$ & 56.1 & 64.8 \\
D-Glucose $(10 \%, \mathrm{w} / \mathrm{v})$ & 73.7 & 92.7 \\
Trehalose $(10 \%, \mathrm{w} / \mathrm{v})$ & 48.5 & 89.7 \\
D-Sorbitol (10\%, w/v) & 59.1 & 93.9 \\
Xylitol (10\%, w/v) & 32.7 & 85.4 \\
D-myo-inositol (10\%, w/v) & 57.3 & 97.0 \\
D-Glycerol (10\%, w/v) & 54.4 & 86.6 \\
Bovine serum albumin (0.1\%, w/v) & 56.7 & 87.0 \\
Bovine serum albumin (1\%, w/v) & 64.9 & 80.6
\end{tabular}

Potential stabilizers were pre-incubated with the enzyme $(0.28 \mathrm{mg}$ of protein $\mathrm{mL}^{-1}$ ) for $180 \mathrm{~min}$ (method A) or added to enzyme solutions of the same protein concentration, which were then frozen and thawed 10 times (method B). The enzyme activity was assayed as described in Methods. The specific activity in the presence of $0.1 \%(\mathrm{w} / \mathrm{v})$ glycine $\left(0.70\right.$ and $0.67 \mathrm{U} \mathrm{mg}^{-1}$ protein in method A and B, respectively) was used as the reference value. Data represent the mean of four independent measurements with relative standard deviation values $<5 \%$.

high ratio of nitrilase to other cellular proteins. However, the output of Nit-ANitRec production was lessened by the low specific activity of the enzyme (at least when using benzonitrile as substrate). When the productivity of Nit-ANigRec and Nit-ANigWT was compared using the preferred substrate of the former enzyme, 2-cyanopyridine, that of the heterologous host was three orders of magnitude higher than that of the native producer.

In comparison with Nit-ANigWT, Nit-ANigRec produced a lower percentage of amide in total product from all substrates tested. With 2-cyanopyridine, the major products of the reaction were different, that is picolinic acid (77\% of total product) and picolinamide ( $>80 \%$ of total product) with the Nit-ANigRec and Nit-ANigWT, respectively. Picolinic acid is an intermediate in the production of pharmaceuticals such as local anaesthetics. Nitrilases with satisfactory activities towards 2-cyanopyridine have rarely been reported. The best activity for this compound (approx. $1 \mathrm{U} \mathrm{mg}^{-1}$ protein) was reported in the thermostable nitrilase from Bacillus pallidus Dac521 [33]. This was much less than the activity determined for Nit-ANigRec $\left(9 \mathrm{U} \mathrm{mg}^{-1}\right.$ protein at $\left.38^{\circ} \mathrm{C}\right)$.

Nit-ANigRec was less stable than the Nit-ANigWT but this drawback could be overcome by using some low-molecular-weight compounds or bovine serum albumin. These compounds, known collectively as osmolytes, have been recognized as efficient agents in protein stabilization [34]. Of the compounds tested, glycine (1\%) was most efficient for the A. niger K10 nitrilase. Glycine and related compounds (sarcosine, betaine) were described as powerful agents able to protect proteins against thermal unfolding $[34,35]$.

Nitrilases forming spiral structures differ from their nonspiral-forming homologs by two insertions of between 12 and 14 amino acids, and a C-terminal extension of up to 35 amino acids [36]. Recently, detailed structural reconstructions using electron microscopy and molecular modelling reported that the formation of spiral helices in the natively produced nitrilases may be related to the removal of $39 \mathrm{C}$-terminal amino acids from the wild-type protein [12]. This post-translational modification was postulated to be due to autocatalytic activity of this enzyme. The approx. 4-kDa difference in molecular weights of Nit-ANigRec and Nit-ANigWT suggested that a similar-sized peptide was cleaved in the latter enzyme. This assumption was verified by mass spectroscopic analysis, indicating missing cleavage of 46 amino acid residues at the C-terminus of Nit-ANigRec. The $R$. rhodochrous nitrilase consisting of full-length subunits was unable to form filamentous structures, which were reported for the post-translationally modified enzyme [12], and also for cyanide hydratase [19,37] and cyanide dihydratase [38]. In accordance with these observations, Nit-ANigWT was to a large extent composed of tube-like structures [17], while Nit-ANigRec exhibited a limited tendency to this arrangement.

The reason for the differences in catalytic properties (substrate specificity, reaction optima, amide formation, stability) between Nit-ANigRec and Nit-ANigWT is not clear but most probably it can be ascribed to differences in the post-translational processing of the two forms of the enzyme, and its subsequent effects on the folding, subunit interaction, and oligomerization of the enzyme. A recent mutational analysis revealed a number of effects caused by deletions or mutations in the C-terminal portion of arylacetonitrilase from Pseudomonas fluorescens EBC191 [39]. In this enzyme, the C-terminal deletions of up to 32 amino acids did not cause any differences in the catalytical properties. However, longer deletions of 47 to 67 amino acids resulted in reduction of enzymatic activity, increased formation of amide, and in changes in the enantiomeric selectivity. The effects caused by C-terminal deletions could be reversed by the addition of the corresponding sequences from another nitrilase [39]. It appears difficult to determine what is the relation of the above changes to those caused by 46 amino acid difference observed in the fungal nitrilase described here, and this issue certainly deserves detailed investigations in the future. It remains also unclear if missing post-translational modification is the primary event leading to partial enzyme misfolding, or if this misfolding negatively affected the autocatalytic cleavage of the enzyme. 
The changes in catalytic behaviour could be also caused by differences in quaternary structure between Nit-ANigRec and Nit-ANigWT. Similarly, a small increase in activity was associated with fibre formation in cyanide dihydratase in Bacillus pumilus [36].

Attempts to express the enzyme in a eukaryotic host (Yarrowia lipolytica; D. Brady et al., personal communication) did not bring about any positive effect on the enzyme activity, which was barely detectable in the yeast cells. The effect of chaperone co-expression in E. coli was not very efficient in the heterologous expression of this enzyme either, though previous experiments suggested the importance of chaperones for the correct folding of proteins of the nitrilase superfamily. Chaperones were co-purified with nitrilases from Bacillus pallidus [33], Pseudomonas fluorescens [40] and A. niger [8] and also played an important role in folding D-carbamoylase [41]. In vitro re-folding of the enzyme from A. niger was also tested as a potential tool to improve its specific activity but did not prove successful. It appears that re-folding is not necessary for heterologous production of fungal cyanide hydratases or nitrilases as a number of them were produced as fully functional enzymes in E. coli [e.g., [12,16,19]].

As far as we know, little or nothing has been reported on the differences between heterologously expressed nitrilases and nitrilases isolated from the native organisms. This is probably because a number of known nitrilases have been purified and characterized either purely from the heterologous host or purely from the native producer. The enzyme with the highest homology to A. niger nitrilase, cyanide hydratase from $A$. nidulans (with $86 \%$ amino acid identity), was only examined with a single substrate (HCN) [16] and not compared with the purified enzyme from the wild-type producer as far as we know. Even if both enzyme forms were available in bacterial nitrilases [e.g., [12,42]], the enzymatic properties have rarely been compared under the same conditions. Therefore, potential differences between the nitrilases isolated from the native organisms and the heterologously expressed nitrilases may have gone unnoticed. Differences in biochemical properties of different nitrilase species may reflect partial misfolding of individual subunits, different post-translational modifications, but the diversity of the enzymes in terms of structural variants (dimers, short spirals, filaments) may be also important in this respect.

\section{Conclusions}

In conclusion, heterologous expression of a fungal nitrilase operating on organic nitriles was achieved in this study for the first time. The enzyme differed from that produced by the wild-type strain A. niger K10 in subunit molecular weight due to a missing post-translational modification (46 C-terminal amino acid cleavage).
Nevertheless, it may still be useful for some biocatalytic applications, and even gained some advantages over the enzyme isolated from the native organism, such as a higher hydrolytic activity for 2-cyanopyridine. Purification of the enzyme from the heterologous host was straightforward, enabling tens of $\mathrm{mg}$ of the purified protein to be obtained for structural and activity studies. The refolded enzyme underwent changes in its oligomeric structure during storage and was finally fractionated to give a structurally almost homogeneous protein potentially useful for crystallographic nitrilase studies, which have so far been largely impaired by specific quaternary arrangement of these enzymes.

\section{Methods}

\section{DNA manipulations}

Total RNA was isolated from A. niger K10 using RNeasy Plant Mini Kit (Qiagen) and used to synthesize cDNA using SuperScript II Reverse Transcriptase (Invitrogen) and anchored oligo $\mathrm{d}(\mathrm{T})_{23} \mathrm{VN}$ primer (NEB). Partial cDNA of the nitrilase gene was amplified using the degenerate forward primer NITR_NTERMFW01, 5'AAY GCI GAR CCI GGI TGG TTY GA-3', derived from the N-terminal fragment sequence NAEPGWFD of Aspergillus fumigatus nitrilases [GenBank:EDP55254, XP_756085] and degenerate reverse primer NITR_INT2RE01, 5'-CAT RTA RTG ICC ICC RAA RTC IGC-3', derived from the internal peptide fragment sequence ADFGGHYM from the same A. fumigatus nitrilases. The PCR product (about $0.9 \mathrm{~kb}$ ) obtained after 35 cycles of PCR on a Mastercycler personal cycler (Eppendorf) with proofreading DNA Polymerase Pfu Turbo (Stratagene) was cloned into the pBluescript SK+ vector (Stratagene) and sequenced using automated DNA sequencer (ABI PRISM 3130xl) according to the manufacturer's protocols.

To obtain 5' and 3' cDNA end sequences, a BD SMART RACE cDNA Amplification Kit (Clontech) was employed. 5'-RACE and 3'-RACE amplifications were performed using 30 cycles of PCR with BD Advantage 2 DNA Polymerase (Clontech). A common universal primer (UPM) was used for the amplifications of cDNA ends together with two distinct gene-specific primers: 5'-RACE reverse primer, NITR_RACE_FW01, 5'-CCG CGT CGG CCA CCT CAA CTG CTG GGA G-3', and 3'-RACE forward primer, NITR_RACE_RE01, 5'-CGT GGA CCT GCT CGC CCA AAG AGG CTG C-3', respectively. The resulting 5'-RACE and 3'-RACE PCR products (approx. 0.6 and $0.7 \mathrm{~kb}$, respectively) were cloned and sequenced as described above.

In order to amplify the DNA fragment coding for the nitrilase sequence, forward primer 5'-GCC ATA TGG CAC CMG TCT TRA AGA AGT ACA A-3', (M = A or $C ; \mathrm{R}=\mathrm{A}$ or $\mathrm{G})$, and reverse primer, 5'-GCA AGC TTT 
TAC TAG TTC TCC GAA TCC ACG GT-3' were used. The corresponding PCR product obtained after 30 cycles of PCR with Taq-DNA polymerase (Clontech) was ligated into the cloning vector pCR 2.1 TOPO (Invitrogen), cloned in One Shot ${ }^{\circledR}$ TOP10 E. coli Competent Cells (Invitrogen) and sequenced as described above.

Database searches were performed using the BLASTX and BLASTP programme $[43,44]$. Alignment of amino acid sequences was performed using ClustalW software [45].

For expression, the NdeI-HindIII fragment was ligated into the corresponding sites of the vectors pET-30a $(+)$ (Novagen) and pRSET B (Invitrogen). The resulting vectors pOK101 and pOK102 were transformed into selected strains of E. coli (see below). Alternatively, E. coli was transformed with plasmid pOK101 and plasmid pTf16 (Takara) containing the tig gene which encodes the trigger factor.

\section{Microbial cultures and plasmids}

A. niger K10 was grown as described previously [8]. E. coli strains were grown in $\mathrm{LB}$ broth at $28^{\circ} \mathrm{C}$ (strains BL21(DE3), BL21-Gold(DE3), BL21-Gold(DE3)pLys, BL21-CodonPlus(DE3)-RIPL, BL21-CodonPlus(DE3)-RIL (Stratagene), Rosetta-gami 2 (DE3) (Novagen)) or $14^{\circ} \mathrm{C}$ (strains Arctic Express(DE3), Arctic Express(DE3)-RP and Arctic Express(DE3)-RIL (Stratagene)). Cultures of strains harbouring plasmid pOK101, pOK102 or both plasmids pOK101 and pTf16 (Takara) were performed with kanamycin $\left(50 \mu \mathrm{g} \mathrm{mL}{ }^{-1}\right)$, ampicillin $\left(150 \mu \mathrm{g} \mathrm{mL}^{-1}\right)$ or ampicillin $\left(150 \mu \mathrm{g} \mathrm{mL} \mathrm{m}^{-1}\right)$ and chloramphenicol $\left(20 \mu \mathrm{g} . \mathrm{mL}^{-1}\right)$, respectively, in addition to selected antibiotics, with resistance to them encoded in the host chromosome, i.e. chloramphenicol $\left(35 \mu \mathrm{g} \mathrm{mL} \mathrm{m}^{-1}\right.$; strain BL21-Gold(DE3)pLys), tetracycline $\left(12.5 \mu \mathrm{g} \mathrm{mL}{ }^{-1}\right.$; strain BL21-Gold (DE3), both chloramphenicol and tetracycline (strains BL21-CodonPlus(DE3)-RIPL and BL21CodonPlus(DE3)-RIL, Rosetta-gami 2(DE3)), or gentamycin (20 $\mu \mathrm{g} \cdot \mathrm{mL}^{-1}$; Arctic Express strains). The expression of nitrilase was monitored after induction with IPTG $(1 \mathrm{mM})$ by nitrilase activity assay using whole cells (see below) and by 12\% SDS-PAGE [46] followed by Coomassie staining.

\section{Enzyme purification}

Nit-ANigRec was purified from the culture of E. coli BL21-Gold(DE3)(pOK101/pTf16). The culture was grown under the following optimized conditions: arabinose $\left(2 \mathrm{~g} \mathrm{~L}^{-1}\right)$ and IPTG $(0.5 \mathrm{mM})$ addition to cultures with $\mathrm{OD}_{610}$ of 0.6 and 1.1 , respectively, and cultivation temperature shift from 37 to $26^{\circ} \mathrm{C}$ after induction with IPTG. The cells were harvested at $\mathrm{OD}_{610} \approx 8.7(16 \mathrm{~h}$ after IPTG addition) and disrupted by sonication. After removing cell debris by centrifugation $\left(13,000 \times \mathrm{g}, 4^{\circ} \mathrm{C}\right.$, $30 \mathrm{~min})$, the supernatant proteins were eluted through a
Hi-Prep 16/10 Q FF column (Amersham Biosciences), with a linear gradient of $\mathrm{NaCl}(0.15-1 \mathrm{M})$ in Tris $/ \mathrm{HCl}$ buffer (50 mM, pH 7.6). Active fractions were pooled, concentrated using an Amicon Ultra-4 unit (cut-off 10 kDa; Milipore) and injected into a Hi-Prep 16/60 Sephacryl S-200 column. The proteins, eluted with Tris $/ \mathrm{HCl}$ buffer $(50 \mathrm{mM}$, pH 7.6, $150 \mathrm{mM} \mathrm{NaCl}$ ), were pooled, concentrated, analyzed by SDS-PAGE as described above and stored at $-80^{\circ} \mathrm{C}$.

The refolded enzyme was purified in two steps consisting in Q-Sepharose HP chromatography and gel filtration on Superose 6 Prep Grade. The sample was injected into a Q-Sepharose HP column $(1.6 \times 11.5 \mathrm{~cm})$ pre-equilibrated with Tris/ $\mathrm{HCl}$ buffer $(50 \mathrm{mM}, \mathrm{pH} 7.5$; $\left.29 \mathrm{mM} \mathrm{NaCl}, 1 \mathrm{mM} \mathrm{NaN}_{3}\right)$. Proteins were eluted with a linear gradient of $\mathrm{NaCl}(0.029-1 \mathrm{M})$ in Tris/ $\mathrm{HCl}$ buffer (50 mM, pH 7.5; $29 \mathrm{mM} \mathrm{NaCl}, 1 \mathrm{mM} \mathrm{NaN}_{3}$ ), concentrated and injected into a Superose 6 Prep Grade column $(1 \times 25 \mathrm{~cm})$. Proteins were eluted with Tris $/ \mathrm{HCl}$ buffer $(50 \mathrm{mM}, \mathrm{pH} 7.5 ; 150 \mathrm{mM} \mathrm{NaCl})$. Those with a molecular weight of approx. $600 \mathrm{kDa}$ (major peak) were collected and stored for one month at $4^{\circ} \mathrm{C}$. Then the gel filtration was repeated, the fractions (eluted as the major peak of approx. $500 \mathrm{kDa}$ ) pooled, concentrated and stored at $4^{\circ} \mathrm{C}$ for a further 10 days. Gel filtration was repeated with this sample and the active fractions analyzed separately for enzyme activity, by analytical centrifugation and by electron microscopy.

Nit-ANigWT was purified as described previously [8].

Protein concentration was determined according to Bradford [47] using bovine serum albumin as the standard.

\section{Refolding}

Refolding conditions were screened using iFOLD Protein Refolding System 1 (Novagen). The purified enzyme (1 mg; $0.1 \mathrm{~mL}$ of Tris/HCl buffer, $\mathrm{pH} 7.6$ ) was mixed with $1 \mathrm{~mL}$ of $6 \mathrm{M}$ guanidine hydrochloride in phosphate-buffered saline (PBS) consisting of $10 \mathrm{mM}$ sodium phosphate buffer ( $\mathrm{pH} 7.4 ; 150 \mathrm{mM} \mathrm{NaCl})$ supplemented with $1 \mathrm{mM}$ of tris(2-carboxyethyl)phosphine hydrochloride and $0.03 \% N$-lauryl sarcosine. Each of the refolding agent mixtures available in iFOLD Protein Refolding System 1 was transferred into a well of a Greiner BioOne UV Star microplate and $0.010 \mathrm{~mL}$ of enzyme solution added into each well. After a 20-h incubation of the microplate with periodic shaking, optical density at $340 \mathrm{~nm}$ was determined using a Safire microplate reader (TECAN). Samples with the lowest level of precipitation were assayed for nitrilase activity.

The refolding conditions selected via the above screening were used on a larger scale (1-10 mg protein). The purified enzyme (1-10 $\mathrm{mg}$ in Tris/ $\mathrm{HCl}$ buffer, $\mathrm{pH}$ 7.5) was denatured as described above in a total volume 
of $10 \mathrm{ml}$. The sample was sonicated and mixed with $90 \mathrm{ml}$ of $50 \mathrm{mM}$ Tris buffer, $\mathrm{pH} \mathrm{7.5}$, containing $100 \mathrm{mM} \mathrm{NaCl}, 20 \%$ glycerol, $12.5 \mathrm{mM}$ methyl- $\beta$-Dcyclodextrin and $1 \mathrm{mM} \mathrm{NaCl}$ (buffer C12 according to iFOLD Protein Refolding System 1; approx. $10 \mathrm{~mL} \mathrm{mg}^{-1}$ protein). Thereafter, the refolding mixture was dialyzed against $2 \mathrm{~L}$ of $50 \mathrm{mM}$ Tris/ $\mathrm{HCl}$ buffer $(\mathrm{pH} 7.5,29 \mathrm{mM}$ $\mathrm{NaCl}, 1 \mathrm{mM} \mathrm{NaN}_{3}$ ). After $4 \mathrm{~h}$ at $4^{\circ} \mathrm{C}$, the dialysis buffer was changed for $2 \mathrm{~L}$ of fresh buffer, and dialysis was left to proceed overnight. The refolded nitrilase was recovered using Q-Sepharose and Superose 6 chromatographies as described above.

\section{Mass spectrometry analysis}

Peptide mass fingerprinting of fragments obtained by tryptic or Asp-N digestion of Nit-ANigRec and NitAnigWT was as decribed previously [8].

\section{Determination of $\mathrm{N}$-terminal amino acid sequence}

The N-terminal sequences of Nit-ANigRec and NitANigWT were analyzed as described previously [8].

\section{Enzyme assays}

The nitrilase activity was determined with $25 \mathrm{mM}$ benzonitrile as described previously [8] with slight modification. If not stated otherwise, reaction temperature was 30 or $38^{\circ} \mathrm{C}$ with recombinant cells or Nit-ANigRec, respectively, instead of $45^{\circ} \mathrm{C}$ with Nit-AnigWT. Substrate specificity was determined using $25 \mathrm{mM}$ of various nitriles as substrates under the above conditions. The substrates and reaction products were analyzed by HPLC.

\section{Analytical HPLC}

Benzonitrile, its analogues, phenylacetonitrile, 2-phenylpropionitrile and the corresponding reaction products (acids, amides) were analyzed using a Chromolith Flash RP-18 (Merck; $25 \mathrm{~mm} \times 4.6 \mathrm{~mm}$ ) in a mobile phase consisting of acetonitrile : water : $\mathrm{H}_{3} \mathrm{PO}_{4}, 200: 799: 1$ (flow-rate $2 \mathrm{~mL} \cdot \mathrm{min}^{-1} ; 35^{\circ} \mathrm{C}$ ). Heterocyclic nitriles and their products were analyzed as described previously [9].

\section{Analytical ultracentrifugation}

Sedimentation velocity and sedimentation equilibrium experiments were performed using a ProteomeLab XL-I analytical ultracentrifuge (Beckman Coulter) using an An50Ti rotor, and dual absorbance and laser interference optics. Before the experiment, $0.5 \mathrm{~mL}$ samples of nitrilase diluted to $0.4 \mathrm{mg} \cdot \mathrm{mL}^{-1}$ were dialyzed for $20 \mathrm{~h}$ against $2 \mathrm{~L}$ of $50 \mathrm{mM}$ Tris- $\mathrm{HCl} \mathrm{pH} 7.5$ with $150 \mathrm{mM}$ $\mathrm{NaCl}$ and $1 \mathrm{mM} \mathrm{NaN}_{3}$, and the dialysis buffer was used as a reference and sample dilution buffer. The sedimentation velocity experiment was conducted at $15,000 \mathrm{rpm}$ and $20^{\circ} \mathrm{C}$ using an epon double-sector cell (Beckman
Coulter). Sample $(400 \mu \mathrm{L})$ and dialysate $(430 \mu \mathrm{L})$ were loaded into the sample and reference cells, respectively. Based on buffer composition and nitrilase amino acid sequence using the program SEDNTERP [48], buffer density and nitrilase partial specific volume were estimated to be 1.00585 g.mL ${ }^{-1}$ and $0.7331 \mathrm{~mL} \cdot \mathrm{g}^{-1}$, respectively. Absorbance scans were performed at $280 \mathrm{~nm}$ with 5 min intervals using a spacing of $0.003 \mathrm{~cm}$ in continuous scan mode and were analyzed with the program SEDFIT [49,50]. A continuous size-distribution for noninteracting discrete species model was calculated and the sedimentation coefficient value determined by integration. Sedimentation equilibrium ultracentrifugation runs were performed with nitrilase concentrations of $0.4,0.2$ and $0.1 \mathrm{mg} \cdot \mathrm{mL}^{-1}$ and at speeds of 3,000, 3,500, $4,000,4,500,5,000,5,500$ and $6,000 \mathrm{rpm}$ in a six-channel epon cell for $16 \mathrm{~h}$ at $20^{\circ} \mathrm{C}$ with 110 and $130 \mu \mathrm{L}$ of sample and reference, respectively. Absorbance data was collected at $280 \mathrm{~nm}$ by averaging 20 scans with radial increments of $0.001 \mathrm{~cm}$ in step scan mode. The sedimentation equilibrium experiments were globally analyzed with the program SEDPHAT version 6.21 [50,51]. The size and shape of the sedimenting species was predicted using the Teller method in the program SEDNTERP.

\section{Dynamic light scattering}

The particle size distribution of the nitrilase solution from individual fractions obtained by gel filtration was assessed using the dynamic light scattering method (Malvern Instruments, ZEN3600) in a low volume glass cuvette $(45 \mu \mathrm{L})$ at $18^{\circ} \mathrm{C}$ with an appropriate enzyme concentration in $50 \mathrm{mM}$ TRIS, $150 \mathrm{mM} \mathrm{NaCl}, 1 \mathrm{mM}$ $\mathrm{NaN}_{3}$, pH 7.5, sample volume $30 \mu \mathrm{L}$. The particle diameter values corresponding to the maxima of peaks in the mass distribution are reported. Molecular weight estimations were made using an empirical mass $v s$. size calibration curve of the instrument software (Dispersion Technology Software 5.03, Malvern Instrument).

\section{Electron microscopy}

Protein complexes were negatively stained (2\% uranyl acetate) on glow discharge activated carbon coated grids [52]. Samples were viewed under a Philips CM100 electron microscope at $80 \mathrm{kV}$. Digital images were recorded using MegaView II slow scan camera at primary magnification of $64,000 \times$ resulting in pixel size of $0.98 \mathrm{~nm}$.

\section{Homology modelling and molecular dynamics}

The search for homologous structures was done with BLAST $[43,44]$. Structures with the highest identity were extracted from the Protein Data Bank and used as templates for modelling. A structure-based multiple sequence alignment was done with the T-Coffee server 
[53] and manually corrected on the basis of consensus secondary structure prediction [54]. Three-dimensional models consisting of all non-hydrogen atoms were constructed with the package Modeller 9.1 [55] and validated with ProSA [56].

YASARA [57] was used for visualization, molecular dynamics simulation (MD) and building the multimeric structure. MD was run in water with Yamber2 force field, with a periodic boundary, in an NPT ensemble (temperature set at $298 \mathrm{~K}$, constant pressure and constant number of particles in the cell). Substrate docking of substrate was done using AutoDock 4.0 [58].

\section{Additional material}

Additional file 1: Alignment of DNA sequences of fungal nitrilase and cyanide hydratase genes (pdf file).

Additional file 2: Electron micrograph of Nit-ANigRec before re-folding (tif file).

Additional file 3: Electron micrograph of Nit-ANigRec after re-folding (tif file).

Additional file 4: PDB-file of the refined homology model of nitrilase subunit, prepared in YASARA.

\section{Acknowledgements}

This work was supported by the Grant Agency of the Academy of Sciences of the Czech Republic (grant number IAA500200708), Ministry of Education of the Czech Republic (grant numbers LC06010, OC09046, and MSM_21620808), Czech Science Foundation (305/09/H008 and 310/09/1407), COST/ESF CM0701 (short-term scientific mission grants no. COST-STSMCM0701-4765 and COST-STSM-CM0701-4766 to A. Malandra) and institutional research concept AV0Z50200510 (Institute of Microbiology). We thank Dr. D. Brady (CSIR Johannesburg, South Africa) and his team for examining the feasibility of $A$. niger K10 nitrilase expression in Yarrowia lipolytica.

\section{Author details \\ 'Institute of Microbiology, Academy of Sciences of the Czech Republic, Vídeňská 1083, CZ-142 20 Prague, Czech Republic. ${ }^{2}$ Department of Biochemistry, Faculty of Science, Charles University in Prague, Hlavova 8, CZ- 12840 Prague, Czech Republic. ${ }^{3}$ Centre of Biocatalysis and Biotransformation, Institute of Systems Biology and Ecology, Academy of Sciences of the Czech Republic, Zámek 136, 37333 Nové Hrady, Czech Republic. ${ }^{4}$ Department of Chemistry, Chemical Engineering and Materials, University of L'Aquila, Via Campo di Pile - Zona industriale di Pile, I-67100 L'Aquila, Italy. ${ }^{5}$ Institute of Macromolecular Chemistry, Academy of Sciences of the Czech Republic, Heyrovského náměstí 2, CZ-162 06 Prague, Czech Republic.}

\section{Authors' contributions}

$L M, K B$ and $O K$ designed research, $L M$ and $K B$ wrote the major parts of the paper. OK, OP, ABV, AR and OŠ carried out the molecular genetic studies. RE and NK designed the homology model. Structural studies were carried out by KB, DK and OV (re-folding, analytical ultracentrifugation), OB (electron microscopy), JD and JD (dynamic light scattering). OK and AM carried out biochemical characterization. JF analyzed and interpreted the gene sequence. VK, MC, KS and MK critically revised the manuscript draft. All authors read and approved the final manuscript.

Received: 23 February 2010 Accepted: 6 January 2011 Published: 6 January 2011

\section{References}

1. Kim JS, Tiwari MK, Moon HJ, Jeya M, Ramu T, Oh D-K, Kim I-W, Lee J-K: Identification and characterization of a novel nitrilase from Pseudomonas fluorescens Pf-5. Appl Microbiol Biotechnol 2009, 83:273-283.

2. Zhu DM, Mukherjee C, Yang Y, Rios BE, Gallagher DT, Smith NN, Biehl ER, Hua L: A new nitrilase from Bradyrhizobium japonicum USDA 110 - Gene cloning, biochemical characterization and substrate specificity. $J$ Biotechnol 2008, 133:327-333.

3. Heinemann U, Engels D, Bürger S, Kiziak C, Mattes R, Stolz A: Cloning of a nitrilase gene from the cyanobacterium Synechocystis sp. strain PCC6803 and heterologous expression and characterization of the encoded protein. Appl Environ Microbiol 2003, 69:4359-4366.

4. Mueller P, Egorova K, Vorgias CE, Boutou E, Trauthwein H, Verseck S, Antranikian G: Cloning, overexpression, and characterization of a thermoactive nitrilase from the hyperthermophilic archaeon Pyrococcus abyssi. Protein Expres Purif 2006, 47:672-681.

5. Podar M, Eads JR, Richardson TH: Evolution of a microbial nitrilase gene family: a comparative and environmental genomics study. BMC Evol Biol 2005, 5:42.

6. Seffernick JL, Samanta SK, Louie TM, Wackett LP, Subramanian M: Investigative mining of sequence data for novel enzymes: A case study with nitrilases. J Biotechnol 2009, 143:17-26.

7. Martínková L, Vejvoda V, Kaplan O, Kubáč D, Malandra A, Cantarella M Bezouška K, Křen V: Fungal nitrilases as biocatalysts: Recent developments. Biotechnol Adv 2009, 27:661-670.

8. Kaplan O, Vejvoda V, Plíhal O, Pompach P, Kavan D, Bojarová P, Bezouška K, Macková M, Cantarella M, Jirků V, Křen V, Martínková L: Purification and characterization of a nitrilase from Aspergillus niger K10. Appl Microbiol Biotechnol 2006, 73:567-575.

9. Malandra A, Cantarella M, Kaplan O, Vejvoda V, Uhnáková B, Štěpánková B, Kubáč D, Martínková L: Continuous hydrolysis of 4-cyanopyridine by nitrilases from Fusarium solani $\mathrm{O} 1$ and Aspergillus niger K10. Appl Microbiol Biotechnol 2009, 85:277-284.

10. Banerjee A, Dubey S, Kaul P, Barse B, Piotrowski M, Banerjee UC: Enantioselective nitrilase from Pseudomonas putida: Cloning, heterologous expression, and bioreactor studies. Mol Biotechnol 2009, 41:35-41.

11. Kiziak C, Conradt D, Stolz A, Mattes R, Klein J: Nitrilase from Pseudomonas fluorescens EBC 191: cloning and heterologous expression of the gene and biochemical characterization of the recombinant enzyme. Microbiology 2005, 151:3639-3648.

12. Thuku RN, Weber BW, Varsani A, Sewell BT: Post-translational cleavage of recombinantly expressed nitrilase from Rhodococcus rhodochrous $\mathrm{J} 1$ yields a stable, active helical form. FEBS J 2007, 274:2099-2108.

13. Wu SJ, Fogiel AJ, Petrillo KL, Hann EC, Mersinger LJ, Di Cosimo R, O'Keefe DP, Ben-Bassat A, Payne MS: Protein engineering of Acidovorax facilis 72W nitrilase for bioprocess development. Biotechnol Bioeng 2007, 97:689-693.

14. Bartling D, Seedorf M, Schmidt RC, Weiler EW: Molecular characterization of two cloned nitrilases from Arabidopsis thaliana: Key enzymes in biosynthesis of the plant hormone indole-3-acetic acid. Proc Natl Acad Sci USA 1994, 91:6021-6025.

15. Osswald S, Wajant H, Effenberger F: Characterization and synthetic applications of recombinant AtNIT1 from Arabidopsis thaliana. Eur $\mathrm{J}$ Biochem 2002, 269:680-687.

16. Basile LJ, Willson RC, Sewell BT, Benedik MJ: Genome mining of cyanidedegrading nitrilases from filamentous fungi. Appl Microbiol Biotechnol 2008, 80:427-435.

17. Vejvoda V, Kaplan O, Bezouška K, Pompach P, Šulc M, Cantarella M, Benada O, Uhnáková B, Rinágelová A, Lutz-Wahl S, Fischer L, Křen V, Martínková L: Purification and characterization of a nitrilase from Fusarium solani O1. J Mol Catal B-Enz 2008, 50:99-106.

18. Wang P, Van Etten HD: Cloning and properties of a cyanide hydratase gene from the phytopathogenic fungus Gloeocercospora sorghi. Biochem Biophys Res Commun 1992, 187:1048-1054.

19. Dent KC, Weber BW, Benedik MJ, Sewell BT: The cyanide hydratase from Neurospora crassa forms a helix which has a dimeric repeat. Appl Microbiol Biotechnol 2009, 82:271-278.

20. Yeom SJ, Kim HJ, Lee JK, Kim DE, Oh DK: An amino acid at position 142 in nitrilase from Rhodococcus rhodochrous ATCC 33278 determines the 
substrate specificity for aliphatic and aromatic nitriles. Biochem J 2008, 415:401-407.

21. Pace HC, Hodawadekar SC, Draganescu A, Huang J, Bieganowski P, Pekarsky Y, Croce CM, Brenner C: Crystal structure of the worm NitFhit Rosetta Stone protein reveals a Nit tetramer binding two Fhit dimers. Curr Biol 2000, 10:907-917.

22. Sakai N, Tajika Y, Yao M, Watanabe N, Tanaka I: Crystal structure of hypothetical protein PH0642 from Pyrococcus horikoshii at $1.6 \mathrm{~A}^{\circ}$ resolution. Proteins 2004, 57:869-873.

23. Kumaran D, Eswaramoorthy S, Gerchman SE, Kycia H, Studier FW, Swaminathan S: Crystal structure of a putative $\mathrm{CN}$ hydrolase from yeast. Proteins 2003, 52:283-291.

24. Lundgren S, Lohkamp B, Andersen B, Piškur J, Dobritzsch D: The crystal structure of $\beta$-alanine synthase from Drosophila melanogaster reveals a homooctameric helical turn-like assembly. J Mol Biol 2008, 377:1544-1559.

25. Barglow KT, Saikatendu KS, Bracey MH, Huey R, Morris GM, Olson AJ, Stevens RC, Cravatt BF: Functional proteomic and structural insights into molecular recognition in the nitrilase family enzymes. Biochemistry 2008, 47:13514-13523.

26. Kozielski F, Schönbrunn E, Sack S, Müller J, Brady ST, Mandelkow E: Crystallization and preliminary $x$-ray analysis of the single-headed and double-headed motor protein kinesin. J Struct Biol 1997, 119:28-34.

27. Laskowski RA, MacArthur MW, Moss DS, Thornton JM: PROCHECK - a program to check the stereochemical quality of protein structures. J Appl Cryst 1993, 26:283-291.

28. Kobayashi M, Yanaka N, Nagasawa T, Yamada H: Primary structure of an aliphatic nitrile-degrading enzyme, aliphatic nitrilase, from Rhodococcus rhodochrous $\mathrm{K} 22$ and expression of its gene and identification of the active site residue. Biochemistry 1992, 31:9000-9007.

29. Harper DB: Fungal degradation of aromatic nitriles. Enzymology of C-N cleavage by Fusarium solani. Biochem J 1977, 167:685-692.

30. Goldlust A, Bohak Z: Induction, purification, and characterization of the nitrilase of Fusarium oxysporum f. sp. melonis. Biotechnol Appl Biochem 1989, 11:581-601.

31. Vejvoda V, Kubáč D, Davidová A, Kaplan O, Šulc M, Šveda O, Chaloupková R, Martínková L: Purification and characterization of nitrilase from Fusarium solani IMI196840. Proc Biochem 2010, 45:1115-1120.

32. O'Reilly C, Turner PD: The nitrilase family of CN hydrolysing enzymes - a comparative study. J Appl Microbiol 2003, 95:1161-1174.

33. Almatawah QA, Cramp R, Cowan DA: Characterization of an inducible nitrilase from a thermophilic bacillus. Extremophiles 1999, 3:283-291.

34. Singh $L R$, Dar $T A$, Rahman S, Jamal $S$, Ahmad F: Glycine betaine may have opposite effect on protein stability at high and low pH values. Biochim Biophys Acta 2009, 1794:929-935.

35. Santoro MM, Liu YF, Khan SMA, Hou L-X, Bolen DW: Increased thermal stability of proteins in the presence of naturally occurring osmolytes. Biochemistry 1992, 31:5278-5283.

36. Sewell BT, Thuku RN, Zhang X, Benedik MJ: Oligomeric structure of nitrilases. Effect of mutating interfacial residues on activity. Ann N Y Acad Sci 2005, 1056:153-159.

37. Woodward JD, Weber BW, Scheffer MP, Benedik MJ, Hoenger A, Sewell BT: Helical structure of unidirectionally shadowed metal replicas of cyanide hydratase from Gloeocercospora sorghi. J Struct Biol 2008, 161:111-119.

38. Jandhyala D, Berman M, Meyers PR, Sewell BT, Willson RC, Benedik MJ: Cyn $D$, the cyanide dihydratase from Bacillus pumilus: gene cloning and structural studies. Appl Environ Microbiol 2003, 69:4794-4805.

39. Kiziak C, Klein J, Stolz A: Influence of different carboxy-terminal mutations on the substrate-, reaction- and enantiospecificity of the arylacetonitrilase from Pseudomonas fluorescens EBC191. Protein Eng Des Sel 2007, 20:385-396

40. Layh N, Parratt J, Willetts A: Characterization and partial purification of an enantioselective arylacetonitrilase from Pseudomonas fluorescens DSM 7155. J Mol Catal B-Enz 1998, 5:467-474

41. Sareen D, Sharma R, Vohra RM: Chaperone-assisted overexpression of an active D-carbamoylase from Agrobacterium tumefaciens AM 10. Protein Expres Purif 2001, 23:374-379.

42. Kobayashi M, Nagasawa T, Yamada H: Nitrilase of Rhodococcus rhodochrous J1 -Purification and characterization. Eur J Biochem 1989, 182:349-356
43. Altschul SF, Madden TL, Schäffer AA, Zhang J, Zhang Z, Miller W, Lipman DJ: Gapped BLAST and PSI-BLAST: a new generation of protein database search programs. Nucleic Acids Res 1997, 25:3389-3402.

44. NCBI/BLAST. [http://blast.ncbi.nlm.nih.gov/Blast.cgi].

45. Thompson JD, Higgins DG, Gibson TJ: CLUSTAL W: Improving the sensitivity of progressive multiple sequence alignment through sequence weighting, position-specific gap penalties and weight matrix choice. Nucleic Acids Res 1994, 22:4673-4680.

46. Laemmli UK: Cleavage of the structural proteins during assembly of the head of bacteriophage T4. Nature 1970, 227:680-685.

47. Bradford MM: A rapid and sensitive method for the quantitation of microgram quantities of protein utilizing the principle of protein-dye binding. Anal Biochem 1976, 72:248-54.

48. John Philo's Software Home Page. [http://www.jphilo.mailway.com].

49. Schuck P: Size distribution analysis of macromolecules by sedimentation velocity ultracentrifugation and Lamm equation modelling. Biophys J 2000, 78:1606-1619.

50. SEDFIT. [http://www.analyticalultracentrifugation.com].

51. Schuck P: On the analysis of protein self-association by sedimentation velocity analytical ultracentrifugation. Anal Biochem 2003, 320:104-124.

52. Benada O, Pokorný V: Modification of the polaron sputter-coater unit for glow-discharge activation of carbon support films. J Electron Microsc Tech 1990, 16:235-239.

53. Notredame C, Higgins DG, Heringa J: T-Coffee: A novel method for fast and accurate multiple sequence alignments. J Mol Biol 2000, 302:205-217.

54. Consensus secondary structure prediction. [http://www.bioinf.manchester. ac.uk/dbbrowser/bioactivity/NPS2.html].

55. Sali A, Blundell TL: Comparative protein modelling by satisfaction of spatial restraints. J Mol Biol 1993, 234:779-815.

56. Wiederstein M, Sippl MJ: ProSA-web: interactive web service for the recognition of errors in three-dimensional structures of proteins. Nucleic Acids Res 2007, 35:W407-W410.

57. Krieger E, Darden T, Nabuurs SB, Finkelstein A, Vriend G: Making optimal use of empirical energy functions: force-field parameterization in crystal space. Proteins 2004, 57:678-683.

58. Morris GM, Goodsell DS, Huey R, Olson AJ: Distributed automated docking of flexible ligands to proteins: Parallel applications of AutoDock 2.4. J Comput-Aided Mol Des 1996, 10:293-304.

doi:10.1186/1472-6750-11-2

Cite this article as: Kaplan et al: Heterologous expression, purification and characterization of nitrilase from Aspergillus niger K10. BMC Biotechnology 2011 11:2.

\section{Submit your next manuscript to BioMed Central and take full advantage of:}

- Convenient online submission

- Thorough peer review

- No space constraints or color figure charges

- Immediate publication on acceptance

- Inclusion in PubMed, CAS, Scopus and Google Scholar

- Research which is freely available for redistribution

Submit your manuscript at www.biomedcentral.com/submit
C Biomed Central 